\title{
Trichodinid ciliates (Peritrichia: Trichodinidae) from the Bay of Kiel, with description of Trichodina claviformis sp. $\mathbf{n}$.
}

\author{
Reimer C. Dobberstein and Harry W. Palm
}

Marine Pathology Group, Department of Fisheries Biology, Institut für Meereskunde an der Universität Kiel, Düsternbrooker Weg 20, D-24105 Kiel, Germany

Key words: Trichodina claviformis, Trichodina jadranica, Trichodina raabei, ectoparasites, Baltic Sea, distribution, host-specificity, identification

\begin{abstract}
Investigations on the epizoic fauna of Gadus morhua (L.), Platichthys flesus (L.) and Oncorhynchus mykiss (Walbaum) from the Kiel Fjord and Kiel Bight were carried out from September 1996 to March 1997. Smears from 120 G. morhua and 92 P. flesus caught using fish traps and trammel nets, and of 35 O. mykiss obtained from a local fish farm in the Kiel Fjord revealed the presence of three species of trichodinid ciliates, Trichodina claviformis sp. n., Trichodina jadranica Haider, 1964 and Trichodina raabei Lom, 1962. The new species can be distinguished from other trichodinids by its large size in combination with the characteristically shaped adhesive disc containing denticles with club-like formed thorns. The thorns are directed anteriorly and not towards the centre of the adhesive disc. As the Kiel Bight and Kiel Fjord are new locality records for T. jadranica and T. raabei, morphological data are provided for both species. Trichodina claviformis is the first record of a peritrichous mobiline ciliate from Atlantic cod of the Baltic Sea. An identification key for 16 Trichodina species occurring on Baltic Sea fishes is provided based on the morphology of the adhesive disc and other well-established features. The occurrence of trichodinid ciliates on G. morhua and P. flesus in the Baltic Sea is discussed, especially considering the biology of the host and a possible host specificity of the species.
\end{abstract}

Marine trichodinid ciliates (Ciliophora: Peritrichia) live as commensals and parasites on various hosts, such as ctenophores (Estes et al. 1997), echinoderms (Precht 1935), echiuroids (Noble 1940), molluscs (Raabe and Raabe 1959, Fenchel 1965, Xu et al. 1995), and fishes. Most of the species are described from the body surfaces and gills of teleosts (Raabe 1959, Lom 1962, Calenius 1980, Van As and Basson 1987), where they feed on waterborne bacteria, small algae, detritus and particles from the host surface (Lom 1973).

In high densities, trichodinid ciliates have been reported to cause severe damage and mortality in juvenile and adult fish populations (trichodiniasis) in aquaculture facilities (Van As and Basson 1987), resulting in heavy financial losses for fish farmers (Moksness et al. 1989). Because of their direct transmission trichodinid ciliates are able to invade their hosts within a short period, especially fish that are kept under less than optimal conditions (Lom 1995). In such cases, they additionally feed on host-cell debris (Lom 1973). Today, trichodinid ciliates have been considered as one of the most common fish parasites in the aquatic environment (Körting et al. 1985). However, the majority of reports focus on trichodinids from freshwater fish, whereas reports from the marine environments are rare (Grupcheva et al. 1989).

In contrast to their economical importance and abundance in the aquatic environment the exact identification of trichodinid ciliates often remains unclear. Today, about 200 species representing ten genera are described within the family Trichodinidae, which are characterised by the length of their adoral ciliary spiral and the shape of the denticles of the adhesive disc (Basson and Van As 1989, Van As and Basson 1993). The largest genus Trichodina comprises more than 170 species. Probably due to the speciesrichness within this family, the recent literature often deals with trichodinids at the genus level. The purpose of the present study is to examine and describe trichodinid ciliates of Atlantic cod Gadus morhua (L.) and common flounder Platichthys flesus (L.), both important economical fish species from the North and Baltic Sea, and of rainbow trout Oncorhynchus mykiss (Walbaum) kept in a net cage in the Kiel Fjord. A new species, Trichodina claviformis sp. n. is described, and an identification key is presented for all currently known trichodinid species from Baltic Sea fish, which enables an exact identification to the species level.

\section{MATERIALS AND METHODS}

A total of 120 Gadus morhua $(11-66 \mathrm{~cm})$ and 92 Platichthys flesus $(10-50 \mathrm{~cm})$ were collected between October 1996 and March 1997 by fish traps (emptied after 3 days) and trammel nets (emptied each $24 \mathrm{~h}$ ) in Kiel Fjord, and in January 1997 by trawl-fisheries in Kiel Bight (also see Palm and Dobberstein 1999). Thirty-five Oncorhynchus mykiss (54-64 $\mathrm{cm}$ ) were obtained from a local fish farm (Aquakulturgesellschaft Ostseeforelle Gbr.) in Kiel Fjord. Smears of skin and fins of nearly equal size $\left(7 \mathrm{~cm}^{2}\right)$ were taken from living or freshly killed specimens. Gill-scrapings were taken from the 
first gill arch. From fish caught by trawl fisheries, only the scrapings of the gills were examined for the presence of trichodinid ciliates. Klein's silver-impregnation technique (Lom 1958) was used to demonstrate the components of the adhesive disc and the adoral ciliary spiral. Air dried smears were slightly washed with distilled water to remove chloride ions by using a Pasteur pipette, left to air dry again, impregnated with a $5 \%$ aqueous solution of silver nitrate $\left(\mathrm{AgNO}_{3}\right)$ for $30 \mathrm{~min}$, again washed with distilled water and exposed to UV light for $30-40 \mathrm{~min}$. All morphological measurements were carried out by oil-immersion light microscopy (Orthoplan, LEITZ). Methods and terminology for measurements of the components of the adhesive disc and the position of the micronucleus in relation to the macronucleus follow those given by Lom (1958). The arithmetic mean, standard deviation and range of the morphometrical data are given in $\mu \mathrm{m}$ unless otherwise indicated. The classification follows Lom (1994).

\section{RESULTS}

During the present study three species of trichodinid ciliates were found. Gadus morhua and Platichthys flesus from the Kiel Bight and the Kiel Fjord were infested with Trichodina claviformis, Trichodina jadranica Haider, 1964 and Trichodina raabei Lom, 1962, the latter being the most common. T. claviformis is the first trichodinid ciliate being described from $G$. morhua of the Baltic Sea. In the following, descriptions and photomicrographs of silver-impregnated specimens of all three species are presented. Prevalence and density data as well as ecological consideration are subject of an other communication (Palm and Dobberstein 1999). The resulting identification key comprises 16 known trichodinid species from the Baltic Sea.

\section{Trichodina claviformis $\mathrm{sp} . \mathrm{n}$.}

Figs. 1-4

Description: Trichodina claviformis is the largest Trichodina species found during this investigation (Figs. 1-3), its cell diameter being about $85.3( \pm 6.7$; 74.7-100.9). In lateral view living cells flattened cylindrical-shaped; in aboral and oral view circular. Adoral ciliary spiral turns $330^{\circ}-370^{\circ}$ before plunging into buccal cavity where it is divided up to the conspicuous buccal ciliature leading to cytostome (Hausmann and Hausmann 1981). Silver-impregnated specimens with bright centre within adhesive disc containing dark granules of irregular shape and size. Diameter of adhesive disc $59.3( \pm 3.9$; 51.1-66.8); denticulate ring $39.2( \pm 3.5 ; 28.2-43.9)$. Width of border membrane $5.4( \pm 0.6 ; 3.9-6.6)$. Denticulate ring consists of 26-27 (25-29) denticles which appear closely connected; 10-11 radial pins per denticle. Number of denticles (Fig. 7) and number of radial pins per denticle (Fig. 8) varies between different specimens. Blade, measuring 5.7 ( $\pm 0.7 ; 3.9-7.2)$, slightly curved, tapering towards end; connection to central part narrow. In some specimens blade reveals sharply curved edge at aperture to central part. Posterior process of central part reaches far into aperture of the following denticle; width of central part $2.3( \pm 0.4 ; 1.7-3.3)$. Thorn short: $3.9( \pm 0.5$; 3.3-5.2). Insertion to central part quite thin, thorn directed anteriorly with characteristic club-like end. Span of denticle 11.7 ( $\pm 1.1 ; 9.2-14.4)$, length of denticle 8.9 ( $\pm 0.7 ; 7.9-10.1)$. Macronucleus horseshoeshaped; outer diameter 45-60. Micronucleus located at inner diameter near the end of the macronucleus in $-y^{1}=2 \mu \mathrm{m}$ position. The morphometrical data are summarised in Table 1.

Some cells have completed binary fission, recognisable by a smaller diameter of the cell and by half the number of radial pins compared to adult cells (Fig. 3). The denticulate ring is divided in two concentric rings; an inner one, revealing about half the number of the denticles (14 in Fig. 4) compared to mature specimens, and being partly resorbed. The second outer ring is newly synthesised (26 denticles in Fig. 4) in order to complete the denticle number.

$\mathrm{Host}$, s ite a nd loc a lity: Trichodina claviformis was most commonly found on the gills of G. morhua, rarely on skin and fins. The hosts were collected from the western Baltic Sea (Kiel Bight and Kiel Fjord), with G. morhua being the type host; few cells were found on the body surfaces of $P$. flesus, the number of specimens were insufficient for statistical analyses of the intraspecific variation.

T y p e h o s t s: Gadus morhua and Platichthys flesus.

Remarks: No corresponding descriptions of marine or brackish fish trichodinids were found. Species of similar size (ranging from about 65-110) are Trichodina cooperi Poynton et Lom, 1989, T. domerguei f. magna Lom, 1961, T. domerguei f. maris-negri Lom, 1962, T. fultoni Davis, 1947, T. hippoglossi Nilsen, 1995, T. murmanica Polyanskiy, 1955 and T. tenuidens FauréFremiet, 1943. The occurrence of T. murmanica on $G$. morhua is recorded by Polyanskiy (1955), Zhukov (1964), Stein (1976) and Poynton and Lom (1989), but this species is smaller (diameter of the cell: 51-72), the number of radial pins per denticle is smaller (7-10), and the thorns of $T$. murmanica are nearly twice as long (6.1). Both, T. cooperi and T. tenuidens, reveal a dark centre of the adhesive disc in silver-impregnated specimens, and $T$. domerguei f. maris-negri reveals a markedly different morphology of the adhesive disc, with larger diameters of cell, adhesive disc and denticulate ring. The description of $T$. hippoglossi was found to be inappropriate because of its different morphology of the adhesive disc and the position of the micronucleus in +y-position (Trichodina claviformis: $-\mathrm{y}^{1}$-position). The thorns of T. domerguei f. maris-negri and T. hippoglossi point towards the centre of the adhesive disc. As the western Baltic Sea reveals a salinity of about 12-17 PSU, the possibility of the occurrence of euryhaline trichodinids, such as T. fultoni 


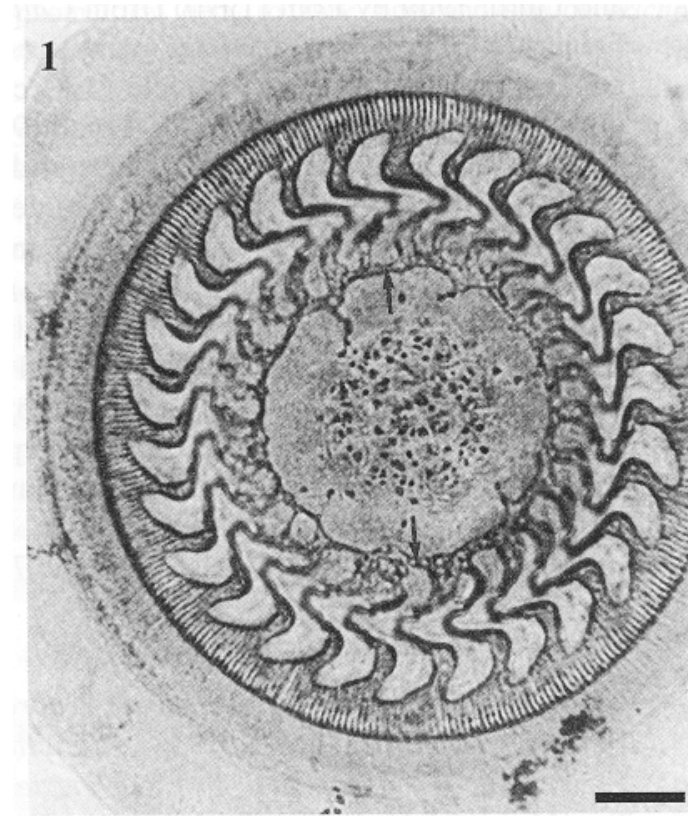

2

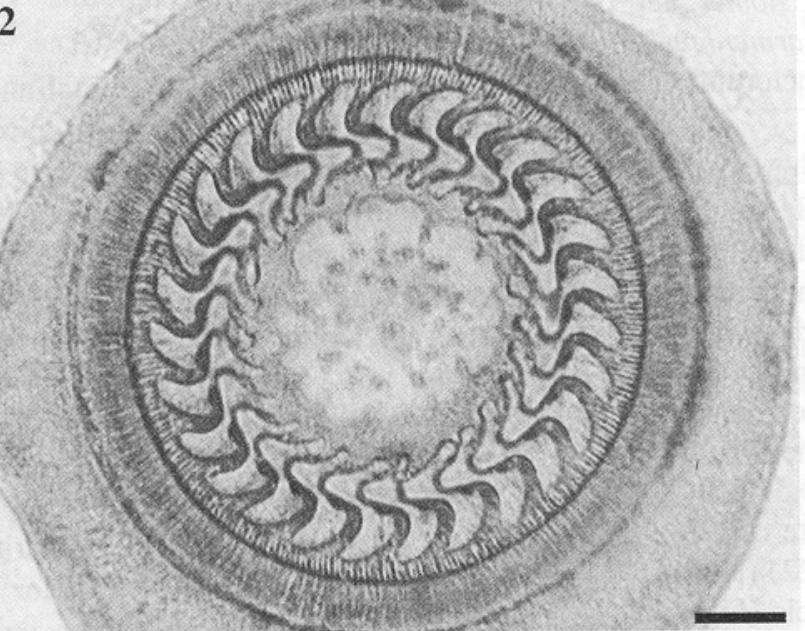

4

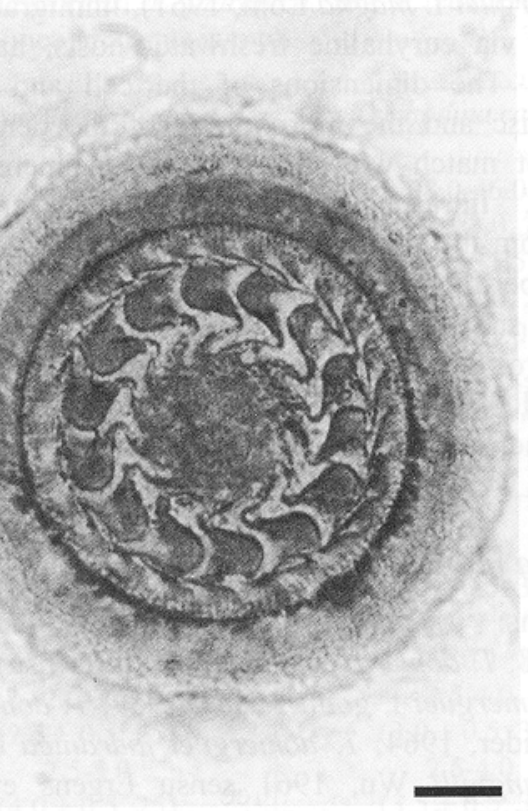

5
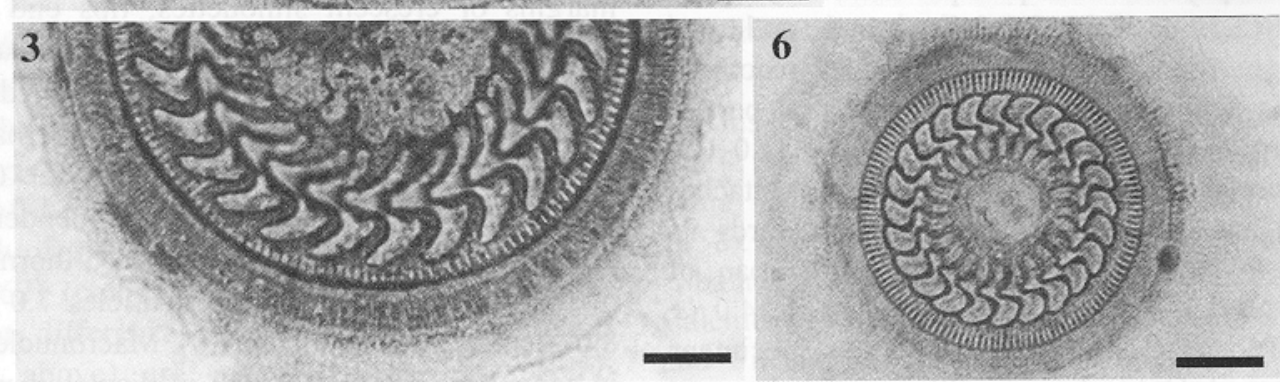

Figs. 1-4. Trichodina claviformis sp. n. from gills of Gadus morhua; adhesive disc, silver impregnation. Fig. 1. Specimen with denticles having club-like thorns (arrow). Fig. 2. Intraspecific variability of the adhesive disc morphology. Fig. 3. Young specimen, indicated by half the number of radial pins per denticle. Fig. 4. Cell after binary fission. Fig. 5. Trichodina jadranica Haider, 1964 from gills of Platichthys flesus; adhesive disc, silver impregnation. Fig. 6. Trichodina raabei Lom, 1962 from gills of Platichthys flesus; adhesive disc, silver impregnation. Scale bars $=10 \mu \mathrm{m}$. 
(=T. domerguei f. magna Lom, 1961), immigrating the Baltic Sea via euryhaline freshwater hosts, has been considered. The dimensions of the cell and of the adhesive disc and the morphology of the denticulate ring do not match with the present specimens of $T$. claviformis. Intraspecific variability between cells sampled from the two different hosts was not regarded as the number of specimens from $P$. flesus were too low for detailed statistical examinations.

Because of the characteristic anteriorly directed clublike formed thorns, which distinguishes $T$. claviformis from all other currently known species within the genus Trichodina, we suggest to establish it as a new species.

\section{Trichodina jadranica Haider, 1964}

Fig. 5

Synonyms: Trichodina domerguei f. jadranica Raabe, 1958; T. domerguei f. pleuronectes sensu Raabe, 1958; T. domerguei f. gobii Raabe, 1959; T. domerguei f. gobii Haider, 1964; T. domerguei jadranica Haider, 1964; T. anguilli Wu, 1961 sensu Ergens et Lom (1970); T. borealis sensu Stein, 1975; T. domerguei sensu Calenius, 1980; T. jadranica armeniensis Grigorian et Stein, 1981; T. anguilli auctorum; $T$. borealis auctorum

Morphology: In oral and aboral view circular, in lateral view hemispherical or dome shaped; height of cell-body never reaches body diameter. Adoral ciliary spiral extends about $400^{\circ}$. In silver impregnation, diameter of cells $34.0( \pm 4.5 ; 26.0-44.5)$. Adhesive disc $(23.0 \pm 3.0 ; 17.0-29.0)$ reveals clear centre, which occasionally contains dark irregularly formed granules or filamentous structures (Fig. 5). Adhesive disc surrounded by border membrane of $2.5( \pm 0.5 ; 1.5-4.0)$ width, finely striated. Diameter of denticulate ring 14.0 $( \pm 1.5 ; 10.0-16.5)$; number of denticles (19-22) (Figs. 5, 7) of sturdy shape; 5-8 radial pins per denticle (Figs. 5, 8). Blades $(2.5 \pm 0.5 ; 2.0-3.5)$ broad and end semicircular in rounded tip; anterior edges reach far onto previous denticle. Blades insert at central part in front of thorn. Short central part $(1.2 \pm 0.1 ; 1.0-1.5)$ opens posteriorly of transition of blade. Thorn attaches in thickened base at central part tapering towards its end. Length of thorn 2.5 ( $\pm 0.5 ; 2.0-3.5)$; span of denticle $6.5( \pm 0.5 ; 5.0-8.0)$, length of denticle $4.0( \pm$ $0.5 ; 2.5-5.0)$. Macronucleus in some specimens horseshoe-shaped. Outer diameter 29, micronucleus not detected. The principal morphometrical data are summarised in Table 1.

Ho s t, s it e a n d 1 o c a 1 it y: Trichodina jadranica was commonly found on the gills of Platichthys flesus, seldom and in a lower intensity on fins and skin. The hosts were collected from the western Baltic Sea (Kiel Bight and Kiel Fjord).

Remarks: This species was identified on basis of the original descriptions of Trichodina jadranica Haider, 1964 by Arthur and Lom (1984) (from Citharichthys spilopterus, Cuba) and T. jadranica (Raabe, 1958) Lom and Laird, 1969 by Lom (1970) (from Calionymus lyra, France). Values for denticle number (19-22) and number of radial pins per denticle (5-8) correspond to the data given for T. jadranica by Lom (1970) (denticle number: 18-23; number of radial pins per denticle: 6-7). Plate IV (figs. 1-4) in Lom (1970) also demonstrates a similar morphology as given in Fig. 5 in the present study. However, the absolute values for diameters of cell, adhesive disc and denticle ring slightly differ between these specimens (compare Table 1 to table 1 in Lom 1970), and T. jadranica in figs. 1, 2 by Arthur and Lom (1984) show a slightly different morphology than that reported for the present specimens. These differences are recognised as cases of intraspecific variation within the species (also see Figs. 7, 8).

\section{Trichodina raabei Lom, 1962}

Fig. 6

Synonyms: Trichodina domerguei f. borealis Dogiel, 1940; T. cottidarum Dogiel, 1948; T. multidentis Laird, 1953 part.; T. domerguei f. pleuronectes StryjeckaTrembaczowska, 1953; T. borealis (Dogiel, 1940) Shulman et Shulman-Albova, 1953.

Morphology: Cells circular in oral and aboral view, in lateral view flat conical. Adoral ciliary spiral turns about $380^{\circ}-400^{\circ}$ before it plunges into buccal cavity. Diameter of silver-impregnated cells (Fig. 6) 43.0 ( \pm $3.0 ; 38.0-46.0)$, diameter of adhesive disc $26.5( \pm 2.0$; 22.5-31.5) revealing darkly stained centre, similar to area between denticles (Fig. 6). Diameter of denticulate ring $17.5( \pm 1.5 ; 14.0-21.0)$. Border membrane $3.0( \pm$ $0.5 ; 2.0-3.5)$ wide, containing fine striation of peripheral pins. Denticulate ring consists of 26-27 (23-29) compactly arranged denticles (Figs. 6, 7), 5-8 radial pins per denticle (Figs. 6, 8). Blades measuring $3.0( \pm 0.5$; $2.5-4.0)$, reveal nearly parallel anterior and posterior margins or crescent silhouettes; tips end bluntly and slightly bend backwards. Central parts relatively short, connection with blades relatively broad. Width of central part $1.3( \pm 0.1 ; 1.0-1.5)$. Thorns broadly insert at central part, taper towards ends, $3.0( \pm 0.5 ; 2.5-4.0)$ long. The whole shape of denticles slender with kneelike curve at transition to central part, thorns and blades of the same length. Span of denticles $7.0( \pm 0.5 ; 6.5-$ $8.0)$, length $3.5( \pm 0.5 ; 2.5-4.0)$. Macronucleus observed in some specimens about 30 in diameter, micronucleus not detected. A summary of the morphometrical data is given in Table 1.

$\mathrm{H}$ o s t, s i t e a n d 1 o c a 1 i t y: Trichodina raabei was found on P. flesus, especially on gills rarely on skin and fins. The hosts were collected from the western Baltic Sea (Kiel Bight and Kiel Fjord).

Remarks: The identification is based on the original description of Trichodina raabei in Lom (1962; plate 1, fig. 11) from Platichthys flesus (Black Sea). Later descriptions by Stein (1976; plate 2, figs. 10, 11) from Limanda limanda (White Sea) and Calenius (1980; 
Table 1. Morphometrical data, locality, host and site of Trichodina claviformis, T. jadranica, and T. raabei (range with arithmetic mean, standard deviation, and number measured in parentheses) (measurements in $\mu \mathrm{m}$ ).

\begin{tabular}{|c|c|c|c|}
\hline Species & Trichodina claviformis & Trichodina jadranica & Trichodina raabei \\
\hline $\begin{array}{c}\text { Diameter of: } \\
\text { cell } \\
\text { adhesive disc } \\
\text { denticulate ring }\end{array}$ & $\begin{array}{c}74.7-100.9 \\
(85.3 \pm 6.7 ; 32) \\
51.1-66.8 \\
(59.3 \pm 3.9 ; 32) \\
28.2-43.9 \\
(39.2 \pm 3.5 ; 32)\end{array}$ & $\begin{array}{c}26.0-44.5 \\
(34.0 \pm 4.5 ; 19) \\
17.0-29.0 \\
(23.0 \pm 3.0 ; 25) \\
10.0-16.5 \\
(14.0 \pm 1.5 ; 25)\end{array}$ & $\begin{array}{c}38.0-46.0 \\
(43.0 \pm 3.0 ; 26) \\
22.5-31.5 \\
(26.5 \pm 2.0 ; 34) \\
14.0-21.0 \\
(17.5 \pm 1.5 ; 34)\end{array}$ \\
\hline $\begin{array}{c}\text { number of denticles } \\
\text { number of radial pins per } \\
\text { denticle }\end{array}$ & $\begin{array}{c}26-27(25-29 ; 32) \\
10-11(32)\end{array}$ & $\begin{array}{c}19-22(25) \\
5-8(21)\end{array}$ & $\begin{array}{c}26-27(23-29 ; 34) \\
5-8(33)\end{array}$ \\
\hline $\begin{array}{c}\text { Shape of denticle: } \\
\text { length of blade } \\
\text { width of central part } \\
\text { length of thorn } \\
\text { length of denticle } \\
\text { span of denticle }\end{array}$ & $\begin{array}{c}3.9-7.2 \\
(5.7 \pm 0.7 ; 32) \\
1.7-3.3 \\
(2.3 \pm 0.4 ; 32) \\
3.3-5.2 \\
(3.9 \pm 0.5 ; 30) \\
7.9-10.1 \\
(8.9 \pm 0.7 ; 32) \\
9.0-14.4 \\
(11.7 \pm 1.1 ; 31) \\
\end{array}$ & $\begin{array}{c}2.0-3.5 \\
(2.5 \pm 0.5 ; 25) \\
1.0-1.5 \\
(1.2 \pm 0.1 ; 25) \\
2.0-3.5 \\
(2.5 \pm 0.5 ; 25) \\
2.5-5.0 \\
(4.0 \pm 0.5 ; 25) \\
5.0-8.0 \\
(6.5 \pm 0.5 ; 25)\end{array}$ & $\begin{array}{c}2.5-4.0 \\
(3.0 \pm 0.5 ; 34) \\
1.0-1.5 \\
(1.3 \pm 0.1 ; 34) \\
2.5-4.0 \\
(3.0 \pm 0.5 ; 34) \\
2.5-4.0 \\
(3.5 \pm 0.5 ; 34) \\
6.5-8.0 \\
(7.0 \pm 0.5 ; 34)\end{array}$ \\
\hline turns of adoral ciliary wreath & $330^{\circ}-370^{\circ}$ & $400^{\circ}$ & $380^{\circ}-400^{\circ}$ \\
\hline $\begin{array}{l}\text { diameter of macronucleus } \\
\text { position of micronucleus }\end{array}$ & $\begin{array}{c}45-60 \\
-y^{1}=2\end{array}$ & $\begin{array}{c}29 \\
\text { not detected }\end{array}$ & $\begin{array}{c}\text { ca. } 30 \\
\text { not detected }\end{array}$ \\
\hline $\begin{array}{c}\text { width of border membrane } \\
\text { position of contractile } \\
\text { vacuole }\end{array}$ & $\begin{array}{c}3.9-6.6 \\
(5.4 \pm 0.6 ; 32) \\
\text { central }\end{array}$ & $\begin{array}{c}1.5-4.0 \\
(2.5 \pm 0.5 ; 23) \\
\text { central }\end{array}$ & $\begin{array}{c}2.0-3.5 \\
(3.0 \pm 0.5 ; 33) \\
\text { central }\end{array}$ \\
\hline $\begin{array}{l}\text { locality } \\
\text { host } \\
\text { site }\end{array}$ & $\begin{array}{c}\text { Kiel Fjord, } \\
\text { Kiel Bight } \\
\text { Gadus morhua, } \\
\text { Platichthys flesus } \\
\text { gills, most rarely skin and } \\
\text { fins }\end{array}$ & $\begin{array}{c}\text { Kiel Fjord, } \\
\text { Kiel Bight } \\
\text { Platichthys flesus } \\
\text { gills, rarely skin and fins }\end{array}$ & $\begin{array}{c}\text { Kiel Fjord, } \\
\text { Kiel Bight } \\
\text { Platichthys flesus } \\
\text { gills, rarely skin and fins }\end{array}$ \\
\hline
\end{tabular}

plate 1, fig. 6) from Platichthys flesus (Åland Islands) also correspond to the present specimens. Values for the diameter of the cell and denticle ring are slightly higher than data given by Lom (1962). However, the dimensions of the denticles, length of the blade, thorn, and the width of the central part correspond to the data by Lom (1962) (compare Table 1 to table 1 in Lom 1962). Slight differences demonstrated in the given figures (see above) are interpreted as intraspecific variability according to Kazubski (1982).

Findings of trichodinid ciliates on Oncorhynchus mykiss were scarce. The small number of specimens found indicates that $O$. mykiss is not a preferred host for the three detected trichodinid species, Trichodina claviformis, T. jadranica and T. raabei. The two cells found were insufficient for a proper identification, especially due to the light staining. However, the cell diameter and the number of denticles was within the range as given for Trichodina claviformis, and not as given for T. jadranica or T. raabei.

\section{Identification key to trichodinid ciliates of Baltic Sea fishes}

This identification key to trichodinid ciliates from the Baltic Sea is based only on reliable original descriptions using Klein's silver-impregnation technique (Lom 1958). The characters used are taken according to Albaladejo and Arthur (1989), Arthur and Lom (1984), Calenius (1980), Kazubski and Migala (1968), Kazubski and Pilecka-Rapacz (1981), Lom (1962, 1970), Lom and Haldar (1976), Lom and Hoffman (1964), Raabe (1959), Rauckis (1983) and Stein (1982).

1 epizoic on gills, skin or fins of fish ..................... 2 - endozoic in the urinary tract of perch

Trichodina urinaria (diam. of cell 74 (64-91), diam. of adhesive disc 48 (40-60), diam. of denticulate ring 24 (21-29), number of denticles 35 (32-37), number of radial pins per denticle 6-8)

2 (1) adhesive disc with bright centre (brighter than between denticles) ............................................. 3

- adhesive disc not completely bright ................... 8 
3 (2) number of denticles $\geq 25$.................................. 4

- number of denticles $<25$ 7

4 (3) number of radial pins per denticle $\geq 10$............. 5

- number of radial pins per denticle $<10$

5 (4) thorn club-shaped, shorter than blade Trichodina claviformis (diam. of cell 82 (71-100), diam. of adhesive disc 57 (47-67), diam. of denticulate ring 38 (28-44), number of denticles 26-27 (25-29), number of radial pins per denticle 10-11)

- thorn straight, nearly as long as blade Trichodina fultoni (diam. of cell 101 (91-112), diam. of adhesive disc 78 (71-86), diam. of denticulate ring 52 (47-58), number of denti-cles 28 (26-31), number of radial pins per denticle 12-14)

6 (4) number of radial pins per denticle 8 , centre of adhesive disc with dark granules, thorn relatively short compared to blade

Trichodina domerguei subsp. domerguei (diam. of cell 52 (36-60), diam. of adhesive disc 40 (33-48), diam. of denticulate ring 25 (21-28), number of denticles 25 (23-28), number of radial pins per denticle 8)

- number of radial pins per denticle $\leq 8$, bright centre of the adhesive disc not contrasted to the area between denticles ........... Trichodina borealis (diam. of cell 50 (42-52), diam. of adhesive disc 37 (33-40), diam. of denticulate ring 25 (23-26), number of denticles 27 (25-30), number of radial pins per denticle 7-8)

(T. borealis is considered nomen dubium, and transferred partly to $T$. jadranica and $T$. raabei)

7 (3) number of radial pins per denticle $\geq 10$

Trichodina acuta

(diam. of cell 57 (52-67), diam. of adhesive disc 48 (42-57), diam. of denticulate ring 30 (28-36), number of denticles 18 (17-19), number of radial pins per denticle 10-12)

- number of radial pins per denticle $<10$ Trichodina jadranica (diam. of cell 43 (34-51), diam. of adhesive disc 25 (20-31), diam. of denticulate ring 14 (11-17), number of denticles 19 (17-21), number of radial pins per denticle 5-7)

8 (2) centre of adhesive disc bright with dark crossing filaments Trichodina reticulata (diam. of cell 61 (57-69), diam. of adhesive disc 46 (46-57), diam. of denticulate ring 34 (31-37), number of denticles 24 (22-26), number of radial pins per denticle 10-12)

- centre of adhesive disc as dark as the area between denticles 9

9 (8) number of radial pins per denticle $\geq 10$.......... 10

- number of radial pins per denticle $<10$.......... 12

10 (9) number of denticles $\geq 24 \ldots \ldots \ldots \ldots \ldots \ldots \ldots \ldots \ldots \ldots . . . . . . . . . . . . . . .11$

- number of denticles $<24$......... Trichodina nigra (diam. of cell 49 (43-54), diam. of adhesive disc 39 (33-44), diam. of denticulate ring 25 (22-29), number of denticles 21 (19-23), number of radial pins per denticle 9-12)
11 (10) number of radial pins per denticle $\geq 12$, width of the border membrane $\geq 6 \mu \mathrm{m}$

Trichodina nobilis

(diam. of cell 79 (70-90), diam. of adhesive disc 65 (58-77), diam. of denticulate ring 44 (39-53), number of denticles 25 (23-28), number of radial pins per denticle 12-14)

- number of radial pins per denticle $<12$, width of the border membrane $<6$... Trichodina tenuidens (diam. of cell 64 (52-81), diam. of adhesive disc 50 (40-65), diam. of denticulate ring 41 (33-53), number of denticles 26 (25-33), number of radial pins per denticle 10)

12 (9) diameter of adhesive disc $\geq 40$ 13

- diameter of adhesive disc $<40$....................... 14

13 (12) thorn nearly twice as long as blade, reaching far into centre of adhesive disc

Trichodina pediculus (diam. of cell 71-104, diam. of adhesive disc 49-58, diam. of denticulate ring 32-38, number of denticles $28-29$, number of radial pins per denticle 7-8)

- length of thorn not twice as long as blade Trichodina tisae (diam. of cell 53 (48-57), diam. of adhesive disc 42 (40-45), diam. of denticulate ring 28 (26-30), number of denticles 25 (23-27), number of radial pins per denticle 7-8)

14 (12) number of denticles 26-27, number of radial pins per denticle $<12$........... Trichodina raabei (diam. of cell 38 (35-40), diam. of adhesive disc 28 (26-32), diam. of denticulate ring 16 (14-18), number of denticles 26 (23-29), number of radial pins per denticle 6)

- number of denticles $<26$, number of radial pins per denticle $<12$ 15

15 (14) number of denticles 22-23, number of radial pins per denticle 7-8 .......... Trichodina modesta (diam. of cell 39 (34-45), diam. of adhesive disc 26 (25-27), diam. of denticulate ring 15 (13-16), number of denticles 22 (21-23), number of radial pins per denticle 7-8)

- number of denticles about 19-26, number of radial pins per denticle 8 , blade crescent-shaped, tip pointing posteriorly .... Trichodina cottidarum (diam. of cell 42 (33-46), diam. of adhesive disc 32 (25-36), diam. of denticulate ring 16 (14-18), number of denticles 23 (19-26), number of radial pins per denticle 8)

In the key, both euryhaline and stenohaline trichodinids are considered due to the high salinity differences between the western and eastern Baltic Sea. However, Trichodina convictor from Alburnus alburnus, Gobio gobio and Scardinius erythrophthalmus; Trichodina esocis from Perca fluviatilis and Stizostedion lucioperca; Trichodina rectangli rectangli from Rutilus rutilus, all recorded by Stein (1982), and Trichodina meridionalis from the body surfaces of Vimba vimba (Rauckis 1983), were recorded from the Kurish Lagoon and adjacent rivers (freshwater). These species were not enclosed as their occurrence is restricted to the freshwater environment. 


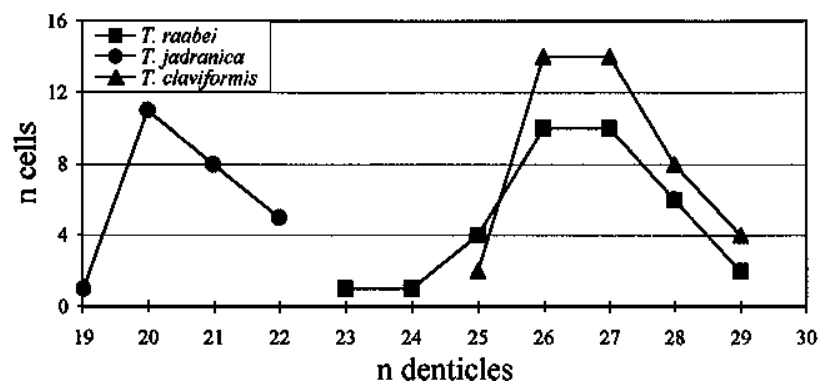

Fig. 7. Denticle number in Trichodina claviformis, Trichodina jadranica and Trichodina raabei, showing intraspecific morphological variability.

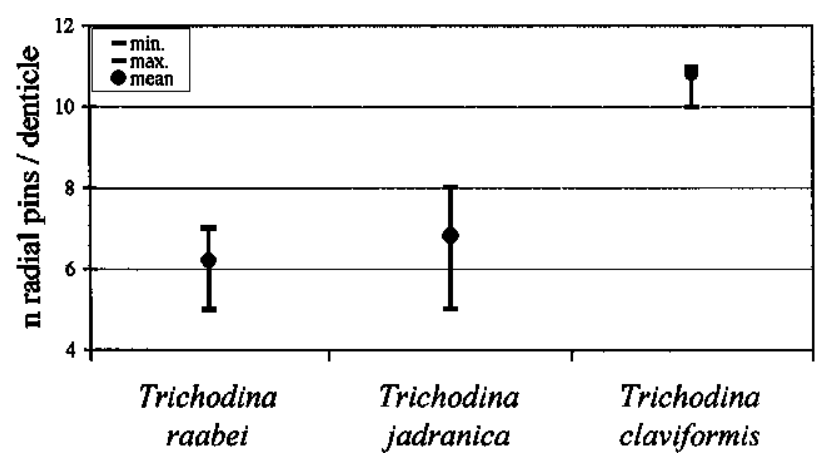

Fig. 8. Number of radial pins per denticle in Trichodina claviformis, Trichodina jadranica and Trichodina raabei, showing intraspecific morphological variability.

\section{DISCUSSION}

The only data on trichodinid ciliates from the western Baltic Sea go back to Precht (1935) and Lüthen (1989). Precht (1935), following the classification of Wallengren (1897), identified trichodinids from threespined sticklebacks in Kiel Fjord as Trichodina domerguei. As these trichodinid ciliates were described without using the silver-impregnation technique (Lom 1958), this finding still needs taxonomical revision. Lüthen (1989), though using the silver-impregnation technique, identified $T$. jadranica and $T$. borealis from economically important flatfish (common dab, European flounder and turbot) off the coast of the former GDR. However, T. borealis is not a valid species due to its original description without using the silverimpregnation technique, no decisive picture of the adhesive disc and a variable size. Thus, the present study establishes new locality records for $T$. jadranica and T. raabei.

Gadus morhua is known to be infested with trichodinid ciliates in North Atlantic waters off Nova Scotia (Poynton and Lom 1989) and in Russian waters (Polyanskiy 1955, Zhukov 1964, Stein 1976). A few species of trichodinid ciliates have been reported previously: Trichodina murmanica mainly infests fins and, occasionally gills of G. morhua in the Barents Sea (Polyanskiy 1955); Poynton and Lom (1989) reported $T$. murmanica, T. cooperi and Trichodina sp. infesting skin and fins of $G$. morhua from Nova Scotian waters. Trichodina claviformis, which mainly infests gills of $G$. morhua, can be added to this list based on the present study. This is the first record of a trichodinid ciliate on G. morhua from the Baltic Sea. The geographical distribution of members within the family Trichodinidae living on G. morhua is therefore extended to the western Baltic Sea.

Platichthys flesus of the Baltic Sea is known to be a common host for trichodinid ciliates, namely Trichodina borealis by Calenius (1980), Lüthen (1989), Rokicki and Morozinska (1994), T. jadranica by Lüthen (1989), Vismanis and Kondratovics (1994) and $T$. raabei by Calenius (1980), Tabolina (1994) and Vismanis and Kondratovics (1994). Additionally, Calenius (1980) found an unidentified trichodinid ciliate which was tentatively identified as Trichodina domerguei subsp. sp. due to the morphology of the denticles. The present study records $T$. jadranica and $T$. raabei from the gills of $P$. flesus caught in the Kiel Fjord and Kiel Bight, confirming that T. jadranica and $T$. raabei are the typical parasites of $P$. flesus from the Baltic Sea, as previously stated by Tabolina (1994) and Vismanis and Kondratovics (1994). Pleuronectiform fish species from various localities of the northern hemisphere were found to be infected by six trichodinid species ( $T$. borealis [see below], T. cottidarum, $T$. frequentis, $T$. jadranica, $T$. nigra and $T$. raabei) (Zhukov 1964, Stein 1967, 1979, MacKenzie 1969, Lom 1970, MacKenzie et al. 1976).

Only two trichodinid cells found on 35 specimens of Oncorhynchus mykiss indicate that this fish is not a preferred host for Trichodina in the western Baltic Sea. Due to the large cell size, the specimens found do not belong to $T$. jadranica or $T$. raabei but were similar in size to $T$. claviformis, which was also detected on Platichthys flesus and Gadus morhua. Thus, T. claviformis might have a wide host range in the eastern Baltic Sea.

The biology of the host influences the prevalence and intensity of its trichodinid burden (Palm and Dobberstein 1999). Bacteria are known to occur adsorbed at surfaces of organic and inorganic particulate matter in a much higher biomass as compared to the free water column (Meyer-Reil 1983). A demersal host such as $P$. flesus enables trichodinids to take advantage of a rich and more stable food supply, compared to a host living temporarily demersal (G. morhua) or pelagic (Clupea harengus, O. mykiss) (Palm and Dobberstein 1999). The free water column has a lower bacterial biomass. Therefore, marine trichodinids can be considered typical parasites of bottom-living fish 
species (Palm and Dobberstein 1999). During the present study, $T$. jadranica and $T$. raabe $i$ were found to infest only the flatfish $P$. flesus, whereas $T$. claviformis could be detected additionally on G. morhua. This finding suggests a different host specificity within Trichodina species (see above), although the hostspecificity of trichodinids in general is considered to be low (Van As and Basson 1992). However, in the northern hemisphere $T$. jadranica was found to infest fish of different families and, in a single case a mollusc (Xu et al. 1995), in both brackish/marine (Raabe 1958, Lom 1970, Stein 1979, 1982, Arthur and Lom 1984, Grupcheva et al. 1989, Vismanis and Kondratovics 1994, Loubser et al. 1995, Imai et al. 1997, Ogawa and Inouye 1997) and freshwater environments (Jusupov and Urasbaev 1980, Grigorian and Stein 1981, Imai et al. 1991). Thus, $T$. jadranica can be considered a widely distributed non-specific ciliate on aquatic organisms. A similar wide range of distribution is known for Trichodina domerguei and Trichodina tenuidens, both living on Gasterosteidae in marine and freshwater environments (Arthur and Lom 1984). T. raabei is reported solely from fish of the family Pleuronectidae from the Baltic Sea (see above), Black Sea (Lom 1962), White Sea (Stein 1976) and in a single case from Pleurogrammus azonus (Hexagrammidae) of the Pacific Basin (Stein 1979). T. raabei demonstrates a preference for flatfishes independently of locality.

The morphometrical data of both $T$. jadranica and T. raabei fall within the same ranges as given for T. borealis. This finding supports the results by Lom (1970) considering T. borealis an invalid species, most probably standing for $T$. jadranica and $T$. raabei. Due to its original description without using the silverimpregnation technique, no given decisive picture of the adhesive disc, and the variable size, $T$. borealis must be considered invalid, questioning the findings by MacKenzie (1969), MacKenzie et al. (1976), Stein (1976), Calenius (1980), Lüthen (1989) and Rokicki and Morozinska (1994). The real identity of the specimens found by these authors still needs to be confirmed. Similar to $T$. borealis, other trichodinids in fact might consist of more than a single species. The wide distribution and low host specificity (see above) might have caused several new descriptions of already existing species. This can explain the enormous amount of about 190 different species within the genus (Lom 1995). Additionally, other events such as temperature were found to cause a changed morphology of the components of the adhesive disc within a single species (Kazubski and Pilecka-Rapacz 1981). The present study also indicates that morphological data of $T$. jadranica and $T$. raabei by other authors do not completely match the mean values of the present specimens (Figs. 7, 8). This can be interpreted as an intraspecific morphological variability within these trichodinids, depending on the host and the temperature of the environment (Kazubski and Pilecka-Rapacz 1981, Kazubski 1982). Thus, descriptions of similar species from different hosts and localities have to be regarded with care, unless further morphological data on intraspecific and interspecific variability within trichodinids are available.

Acknowledgements. We wish to thank Dr. Jiří Lom, Institute of Parasitology, Academy of Sciences of the Czech Republic, České Budějovice, for confirming Trichodina claviformis as a new species, and for kindly revising an earlier draft of the manuscript. We are indebted to $\mathrm{T}$. Jäger, Aquakulturgesellschaft Ostseeforelle Gbr., who gave access to specimens of sampled $O$. mykiss.

\section{REFERENCES}

ALBALADEJO J.D., ARTHUR J.R. 1989: Some trichodinids (Protozoa: Ciliophora: Peritrichida) from freshwater fishes imported into the Philippines. Asian Fish Sci. 3: 1-25.

ARTHUR J.R., LOM J. 1984: Some trichodinid ciliates (Protozoa: Peritrichida) from Cuban fishes, with a description of Trichodina cubanensis $\mathrm{n}$. sp. from the skin of Cichlasoma tetracantha. Trans. Am. Microsc. Soc. 103: 172-184.

BASSON L., VAN AS J.G. 1989: Differential diagnosis of the genera in the family Trichodinidae (Ciliophora: Peritrichida) with the description of a new genus ectoparasitic on freshwater fish from southern Africa. Syst. Parasitol. 13: 153-160.

CALENIUS G. 1980: Parasites of fish in Finland. III. Ciliates of the family Urceolariidae. Acta Acad. Abo. Ser. B 40 (3): $1-16$.

ESTES A.E., REYNOLDS B.S., MOSS A.G. 1997: Trichodina ctenophorii n. sp., a novel symbiont of ctenophores of the northern coast of the Gulf of Mexico. J. Euk. Microbiol. 44: 420-426.
FENCHEL T. 1965: Ciliates from Scandinavian molluscs. Ophelia 2: 71-174.

GRIGORIAN D.A., STEIN G.A. 1981: Parasitic ciliates (Peritricha, Urceolariidae) of some fishes from water bodies of Armenia. Parazitologiya 15: 305-312. (In Russian.)

GRUPCHEVA G., LOM J., DYKOVÁ I. 1989: Trichodinids (Ciliata: Urceolariidae) from gills of some marine fishes with the description of Trichodina zakai sp. n. Folia Parasitol. 36: 193-207.

HAUSMANN K., HAUSMANN E. 1981: Structural studies on Trichodina pediculus (Ciliophora, Peritricha). I. The locomotor fringe and the oral apparatus. J. Ultrastruct. Res. 74: 131-143.

IMAI S., INOUYE K., KOTANI T., OGAWA K. 1997: Two trichodinid species from the gills of cultured tiger puffer, Takifugu rubripes, in Japan, with a description of a new species. Fish Pathol. 32: 1-6.

IMAI S., MIYAZAKI H., NOMURA K. 1991: Trichodinid species from the gills of cultured Japanese eel, Anguilla 
japonica, with the description of a new species based on light and scanning electron microscopy. Eur. J. Protistol. 27: 79-84.

JUSUPOV O.J., URASBAEV A.N. 1980: Parasitic ciliates (Peritricha: Urceolariidae) of fishes from the Aral Sea. Parazitologiya 14: 504-210. (In Russian.)

KAZUBSKI S.L. 1982: Studies on interpopulational variation in trichodinas (Ciliata). Acta Protozool. 21: 135-148.

KAZUBSKI S.L., MIGALA K. 1968: Urceolariidae from breeding carp - Cyprinus carpio L. in Zabieniec and remarks on the seasonal variability of trichodinids. Acta Protozool. 6: 137-160.

KAZUBSKI S.L., PILECKA-RAPACZ M. 1981: Morphological variability of Trichodina nigra Lom (Ciliata, Peritrichida), a parasite of Lucioperca lucioperca (L.) from Szczecin Gulf. Acta Protozool. 20: 103-107.

KÖRTING W., NEEDHAM T., WOOTTEN R. 1985: Parasiten der Knochenfische. In: R.J. Roberts and H.-J. Schlotfeld (Eds.), Grundlagen der Fischpathologie. Verlag Paul Parey, Berlin, Hamburg, pp. 221-265.

LOM J. 1958: Contribution to the systematics and morphology of endoparasitic trichodinids from amphibians, with a proposal of uniform specific characteristics. J. Protozool. 5: 251-263.

LOM J. 1961: Ectoparasitic trichodinids from fresh water fish in Czechoslovakia. Acta Soc. Zool. Bohemoslov. 25: 215228.

LOM J. 1962: Trichodinid ciliates from fishes of the Rumanian Black Sea coast. Parasitology 52: 49-61.

LOM J. 1970: Trichodinid ciliates (Peritrichida: Urceolariidae) from some marine fishes. Folia Parasitol. 17: 113-125.

LOM J. 1973: The adhesive disc of Trichodinella epizootica ultrastructure and injury to the host tissue. Folia Parasitol. 20: 193-202.

LOM J. 1995: Trichodinidae and other ciliates (Phylum Ciliophora). In: P.T.K. Woo (Ed.), Fish Diseases and Disorders, Vol. 1. Protozoan and Metazoan Infections. CAB International, Wallingford, pp. 229-262.

LOM J., HALDAR D.P. 1976: Observation on trichodinids endocommensal in fishes. Trans. Am. Microsc. Soc. 95: 527-541.

LOM J., HOFFMAN G.L. 1964: Geographic distribution of some species of trichodinids (Ciliata: Peritricha) parasitic on fishes. J. Parasitol. 50: 30-35.

LOM J., PUYTORAC P. de 1994: Sous-classe des Peritrichia Stein, 1994. In: P.P. Grassé (Ed.), Traité de Zoologie, Tome II, Infusoires Ciliés, Fasc. 2, Systématique. Masson, Paris, Milan, Barcelona, pp. 681-737.

LOUBSER G.J.J., VAN AS J.G., BASSON L. 1995: Trichodinid ectoparasites (Ciliophora: Peritrichida) of some fishes from the Bay of Dakar, Senegal (West Africa). Acta Protozool. 23: 211-216.

LÜTHEN K. 1989: Fischkrankheiten und Parasiten von Flunder, Scholle, Kliesche und Steinbutt in den Küstengewässern der DDR. Ph.D. thesis, Päd. Hochschule "Lieselotte Herrmann", Güstrow, 186 pp.

MacKENZIE K. 1969: Scyphidia (Gerda) adunconucleata n. sp. and Trichodina borealis (Dogiel, 1940) Shulman et
Shulman-Albova, 1953 (Protozoa: Ciliata) from young plaice in Scottish waters. J. Fish Biol. 1: 239-247.

MacKENZIE K., McVICAR A.H., WADDELL I.F. 1976: Some parasites of plaice Pleuronecta platessa L. in three different farm environments. Scott. Fish. Res. Rep. 4: 114.

MEYER-REIL L.A. 1983: Benthic response to sedimentation events during autumn to spring at a shallow water station in the western Kiel Bight. Mar. Biol. 77: 247-256.

MOKSNESS E., GJØSÆTER J., REINERT A., FJALLSTEIN I.S. 1989: Start-feeding and on-growing of wolffish (Anarhichas lupus) in the laboratory. Aquaculture 77: 221228.

NOBLE G.A. 1940: Trichodina urechi n. sp. an entozoic ciliate from the echiuroid worm, Urechis caupo. J. Parasitol. 26: 387-405.

OGAWA K., INOUYE K. 1997: Parasites of cultured tiger puffer (Takifugu rubripes) and their seasonal occurrence, with description of two new species of Gyrodactylus. Fish Pathol. 32: 7-14.

PALM H.W., DOBBERSTEIN R.C. 1999: Occurrence of trichodinid ciliates (Peritricha: Urceolariidae) in the Kiel Fjord, Baltic Sea, and its possible use as a biological indicator. Parasitol. Res. 85: 726-732.

POLYANSKIY J.J. 1955: Parasites of the fish of the Barents Sea. Trans. Zool. Inst. Acad. Sci. USSR 19, 158 pp. (Israel Program Sci. Transl., Jerusalem, 1966; translated from Russian.)

POYNTON S.L., LOM J. 1989: Some ectoparasitic trichodinids from Atlantic cod, Gadus morhua L., with a description of Trichodina cooperi n. sp. Can. J. Zool. 67: 1793-1800.

PRECHT H. 1935: Epizoen der Kieler Bucht. Nova Acta Leopold. 3: 405-474.

RAABE Z. 1958: On some species of Trichodina (CiliataPeritricha) of gills of Adriatic fishes. Acta Parasitol. Pol. 6: 355-362.

RAABE Z. 1959: Urceolariidae of gills of Gobiidae and Cottidae from Baltic Sea. Acta Parasitol. Pol. 7: 441-452.

RAABE J., RAABE Z. 1959: Urceolariidae of molluscs of the Baltic Sea. Acta Parasitol. Pol. 7: 453-465.

RAUCKIS E. 1983: Parasitic infection of the Baltic-Nemunas Basin population of Vimba vimba during the spawning migration. Acta Parasitol. Lituan. 20: 33-40. (In Russian.)

ROKICKI J., MOROZINSKA J. 1994: Diseases and parasites of flounder Platichthys flesus from the mouth of Vistula River. Diseases and parasites of flounder in the Baltic Sea, BMB Publ. 15: 57-60.

STEIN G.A. 1967: Parasitic ciliates (Peritricha, Urceolariidae) of some fishes of the Kamtchatka. Acta Protozool. 4: 291305. (In Russian.)

STEIN G.A. 1976: Parasitic ciliates (Peritricha, Urceolariidae) of fishes of the White Sea. Acta Protozool. 15: 447-468. (In Russian.)

STEIN G.A. 1979: New data on parasitic ciliates (Peritricha, Urceolariidae) of fishes of the basin of Pacific Ocean. Acta Protozool. 18: 531-552. 
STEIN G.A. 1982: Parasitic ciliates (Peritrichida, Trichodinidae) of some fishes of the Kurish Gulf. Parazitologiya 16: 24-29. (In Russian.)

TABOLINA I. 1994: Parasites and diseases of flounder in the coastal waters of Latvia. Diseases and parasites of flounder in the Baltic Sea, BMB Publ. 15: 61-63.

VAN AS J.G., BASSON L. 1987: Host specificity of trichodinid ectoparasites of freshwater fish. Parasitol. Today 3: 88-90.

VAN AS J.G., BASSON L. 1992: Trichodinid ectoparasites (Ciliophora: Peritrichida) of freshwater fishes of the Zambesi River System, with a reappraisal of host specificity. Syst. Parasitol. 22: 81-109.

VAN AS J.G., BASSON L. 1993: On the biology of Pallitrichodina rogenae gen. n., sp. n. and P. stephani sp. n. (Ciliophora: Peritrichida), mantle cavity symbionts of the giant African snail Achatina in Mauritius and Taiwan. Acta Protozool. 32: 47-62.

VISMANIS K., KONDRATOVICS E. 1994: Parasites of flounder (Platichthys flesus) in the eastern part of the Baltic Sea. Diseases and parasites of flounder in the Baltic Sea, BMB Publ. 15: 77-80.

WALLENGREN H. 1897: Zur Kenntnis der Gattung Trichodina Ehrbg. Biol. Zentralbl. 17: 55-65.

XU K., LEI Y., SONG W. 1995: Morphological studies on Trichodina jadranica Raabe, 1958, a scallop parasite (Protozoa: Ciliophora: Peritricha). J. Ocean-Univ. Quingdao 25: 321-326.

ZHUKOV E.V. 1964: On the parasite fauna of fishes of the Chukotsk Peninsula and the adjoining seas. III. The parasitic Protozoa of marine and freshwater fishes. Parazitol. Sb. 22: 224-253. (In Russian.) 